\title{
Are Nation and Exile a Woman? - the case of David Albahari's novel Bait
}

\author{
Milan MiljKOvić \\ Institute for Literature and Arts, Belgrade
}

In many symbolic representations of the nation or the state, which can be found in art, politics and literature, female figures are very often used: figures of girls, virgins, women and mothers. This use of women's images is in itself ambiguous because, although it may appear to semi-deify women strongly and positively, it more often masks their actual political powerlessness within the social or cultural milieu. ${ }^{1}$ With regards to the context of the Serbian tradition of representing the nation or ethnic community, there are several, historically significant examples of such women, for example, Queen Milica, the mother of the Jugović brothers, or the Kosovo Maiden. ${ }^{2}$ Their characters and their lives have been usually represented within the national-romantic code as the voices of collective grief and martyrdom, or as characters dedicated to the wider national cause. However, there are scholars who claim that these female characters actually represent the alternative, non-traditional and non-patriarchal view of the Kosovo myth and the national identity:

Figures such as Queen Milica, the mother of the Jugović brothers and the Kosovo Maiden were portrayed as inventive in looking for compromises and for survival in a new political and social situation [after the Kosovo battle in 1389], and amongst other ethnic and religious groups. They procured new narratives and new social and religious cults to ease the pain of both the male and female communities; and in their

\footnotetext{
* This article is an expanded version of a presentation delivered at the University of Nottingham in June 2011. The author owes a debt of gratitude to Dr. Uroš Tomić for useful and valuable comments during the writing of the paper as well as careful proofreading of the finished text.

${ }^{1}$ Kirsten Stirling, Bella Caledonia: Woman, Nation, Text, Amsterdam: Rodopi, 2008

2 Queen Milica was the spouse of the duke Lazar, one of the most influential political figures in the period of feudal fragmentation of Serbia in the second half of the fourteenth century. The mother of the Jugovic brothers and the Kosovo Maiden are the female characters from Serbian epic poems that narrate the events that took place before and after the Kosovo battle in 1389. Together with Queen Milica, they represent female heroes closely related to the Kosovo myth which has been used as one of the milestones of the Serbian cultural, historical and political memory. In the epic poems, these characters are trying to prevent their loved ones from going to battle, they oppose men's decision to fight the Turks; at the end, they are the ones who bear tragic consequences of men's behaviour.
} 
secluded female space of oral tradition, they ridiculed those highly masculine tones of the Kosovo myth and the behaviour of epic heroes. ${ }^{3}$

Whether the idea of the nation is embodied in the image of the victimised female hero or the heroic self-sacrificing mother, it is usually the patriarchal code that, on the one hand neutralizes sexual and gender identity of women, and on the other, subdues female figures by transforming them into male-like heroines or martyrs. However, in the light of the diverse relationships between the issues of masculinity and femininity, as well as the representation of the nation and the subversive potential of the female narratives, it is worthwhile considering the possibilities of engendering the nation in a way that could introduce alternative paradigms of national identity.

Instead of masculine strength, power and virility - all predominantly patriarchal categories - the concept of the nation might be redefined in terms of historical feminine experience of exclusion (in terms of gender, social status, education, political power etc) and its specific 'corporeal memory'. This approach replaces commemorative narratives of the national identity with the suppressed personal histories of women. ${ }^{4}$ Furthermore, if nationalism 'is an assertion of belonging in and to the place, a people, a heritage, ${ }^{5}$ then women's testimonial renderings of communal historical experience could, due to their sense of non-belonging and exclusion, establish an important ground for the detailed analysis of the exile experience as an alternation of the concept of the nation (especially in the case of the internal exile). Since 'nationalisms are about groups and exile is a solitude experienced outside the group' the presence of women's voices in history represent one of the possible answers to the question Edward Said poses: 'How, then, does one surmount the loneliness of exile without falling into the encompassing and thumping language of national pride, collective sentiments, group passions?'. ${ }^{6}$

This issue of loneliness becomes particularly problematic in the case of internal exile because the subject is heavily surrounded by the dominant discourses of the nation's ethnic and linguistic purity, which become particularly overwhelming in time of war and socio-political or economic crises. The term, internal exile, is used here in regards to the

\footnotetext{
${ }^{3}$ Svetlana Slapšak, 'Women's Memory in the Balkans: the alternative Kosovo myth', in Gender and Nation in South Eastern Europe, ed. Karl Kaser \& Elisabeth Katschnig-Fasch, Wien: LIT, 2005, p. 109

${ }^{4}$ Tatjana Aleksić, 'Extrication the Self from History: David Albahari's Bait', Journal of the Midwest Modern Language Association, vol. 39, no. 2, 2006, p. 62.

${ }^{5}$ Edward Said, Reflections on Exile: and Other Literary and Cultural Essays, London: Granta, 2001, p.176.

${ }^{6}$ Ibid., p. 177.
} 
explanation given by Paul Allatson and Jo McCormack, where they primarily refer to the concept of Hamid Naficy:

Beyond those sites of official dislocation [penitentiary, the prison camp, the asylum, the house converted into a prison], supposedly benign institutions such as the familial home, and social conditions such as enforced or prolonged unemployment, may also function as sites of exile. ${ }^{7}$

In regards to the model of the external exile, where the subject is physically and geographically distanced from his homeland, certain traces of the feminine experience could also be recognised. As Amos $\mathrm{Oz}$ describes in one of his interviews, the state of exile implies that someone is always at the 'wrong place'. ${ }^{8}$ Using the image of a Jewish woman who is, after her arrival in Israel from Poland, sitting on a bench in the kibbutz singing of Poland in Polish, Amos Oz explains that his own source of creative inspiration lies in the profound sense of lack, displacement and otherness. In the same way as the woman singing of the other land, the one that is no longer hers, Amos Oz embraces the state of chronic homelessness as the foundation of a new type of identity. To live in diaspora means to immerse oneself into the ambiguous sense of being at home while, at the same time, being constantly disseminated and dispersed; the term itself comes from the Greek, where dia means 'apart' and speirein means not just 'to scatter' but also 'to sow'. In light of this etymological explanation, Maaera Shreiber suggests that the traditional opposition between home and exile should be imbalanced and redefined in order to understand the exile as a type of home that is always on the move.

Therefore, one of the core questions of this article is related to the possibility of engendering the nation and the exile in a way that would allow us not just to redefine these traditional, and very often patriarchal, concepts but to blend them by using the women's experience of the internal exile, and yet, to keep the conceptual difference between the nation and the exile. The feminine notion of the exile and Julia Kristeva's concept of the female voyager - 'who is able to travel through discourses and who refuses to

\footnotetext{
7 Paul Allatson, Jo McCormack, eds., Exile Cultures, Misplaced Identities, Amsterdam: Rodopi, 2008, p. 11.

${ }^{8}$ Maeera Y. Shreiber, 'The End of Exile: Jewish Identity and Its Diasporic Poetics', PMLA, vol.

113, no. 2, 1998, p. 274. Amos Oz, born in Jerusalem, with parents who came from Eastern Europe, is an

Israeli writer, novelist and journalist whose literary work and intellectual efforts are related to the issue of displacement, national identity, Diaspora, and also to the question of the Israeli-Palestinian conflict.

${ }^{9}$ Ibid., p. 274.
} 
domesticate the structures that surround her ${ }^{10}$ - will be used in order to articulate the position of the continuous internal exile which can, within the dominant discourses and paradigms of national culture, always produce a sense of becoming a stranger to one's own country, language, sex and identity.

\section{David Albahari's Bait}

Published in 1996, Bait received one of the most prominent literary awards in Serbia - the NIN literary award for best novel - and gained a lot of praise from a variety of distinguished literary critics in Serbia. The story of the novel is presented by the narrator who has just committed an action of self-exile, from Serbia to Canada after the death of his mother and at the time of ongoing wars in the Balkans (Croatia and Bosnia and Herzegovina). The novel consists of two parallel stories that are interconnected and constantly being interrupted. One of the stories is set in Canada, and it depicts the meetings between the narrator and his Canadian friend Donald. They talk about writing, cultural differences and stereotypes concerning America, Europe, and the Balkans. In the second story thread, the narrator listens to a series of audio tapes recorded with his mother years before. He reflects on her life and their relationship while trying to come to terms with a new life of his own - that of exile and the confusion of new cultural adjustments.

As one of his seminal literary works, Bait represents the marking point in Albahari's creative and literary transition from the postmodern narrative experimentation in the 1980s, focused on personal or familial experiences, to novels and fictional works that are much more preoccupied with the questions of historical and sociopolitical identities. ${ }^{11}$ This transition was strongly influenced by the Yugoslav socio-political milieu, which was, at the beginning of the 1990s, determined by the economic crisis, 'massive abuse of historic discourse' and nationalistic revisions of the 'past which was the common denominator around which the subsequent civil wars revolved'. ${ }^{12}$ Therefore, in the last decade of the twentieth century, it was almost impossible for writers (both poets and

\footnotetext{
10 Anna Smith, Julia Kristeva. Readings of Exile and Estrangement, New York: St Martin's Press, 1996, p. 57.

11 Vladislava Ribnikar, 'History as Trauma in the Work of David Albahari', Serbian Studies, vol. 19, no. 1, 2005, pp. 15-24.

12 Tatjana Aleksić, 'Extrication the Self from History: David Albahari's Bait', Journal of the Midwest Modern

Language Association, vol. 39, no. 2, 2006, p. 66.
} 
novelists) to avoid a whole range of politically contaminated literary topics which were marked by the overwhelming ideological discourses of national awakening and martyrdom.

This article represents an attempt to shed some light on those aspects of the novel that reveal how the inscription of gender ambiguity and the feminine internal exile into the concept of national identity could destabilise the patriarchal narrative of the nation in the 1990s. The main focus (or the dream) of this study will be the character of the narrator's mother in the said novel. She is perceived by the readers only as a voice on the tape (made after the death of the narrator's father), accompanied by a variety of unintentionally recorded non-verbal sounds and silences that constitute an important element of the mother's gestural language. Analogous to the multiple configurations of the mother's voice - it had been taped by the narrator, then listened to in Canada, and finally transferred into the kaleidoscopic pseudo-autobiographical novel - the mother's character represents a fragmented model of the national identity mélange. Consequently, she offers an opportunity for the reader to contest continually the monolithic perception and representation of the nation, by recognizing and embracing the sense of estrangement and exile within himself/herself, because 'we can only respect incompatible differences within communities if we confront the fact that we are too split subjects'.13

Before proceeding, it is worth recollecting the difference between the meaning, and therefore, the potential performative strength of the two verbs, to focus and to dream, which is delicately emphasised by Jane Gallop ${ }^{14}$. While the verb to focus denotes an attempt to structure the literary interpretation in an almost mathematically precise and sharp manner, to dream, especially in the psychoanalytic practice, refers to a different interpretational dynamic. It introduces 'the uncanny self-knowledge where subject and object are neither identical nor different, where the subject and object of the knowledge are aspects of the 'same person' separated by the opaque materiality of the dream'15. This distinction is useful both for the analysis of the characters' relationships in the novel and for the dialogue between the interpreter and the text because it stresses the fluidity of the identity difference. In order to, more or less successfully, grasp the alterity of the mother's voice in Bait, it is important that the reader articulate an interpretation which would not

\footnotetext{
13 Anna Smith, Julia Kristeva. Readings of Exile and Estrangement, New York: St Martin's Press, 1996, p. 23.

${ }_{14}$ Jane Gallop, 'Reading the Mother Tongue: Psychoanalytic Feminist Criticism', Critical Inquiry, vol. 13, no.

2, 1987 , p. 320

${ }^{15}$ Ibid., p. 321.
} 
(un)intentionally suppress but affirm the possibility of non-patriarchal modes of national and exile identities.

\section{Inner Exile between the Nation and History}

From the novel's beginning the reader learns how important the mother was for the family during the Second World War. Her personal stubbornness - symbolically represented in the stereotypical 'hard Bosnian head' - and her decisive choices made in order to save her children from the horrors of war, actions that were usually associated with male protagonists, elevate her character into the patriarchal figure of the mother who willingly endures the burden of her children's Jewish otherness. Even though she was born Serbian, her decision to convert to Judaism at the outbreak of war simultaneously emphasises the traditional model of the nation related to ethnic origins and the model where the collective identity is a matter of active choice, thus implicitly illustrating the idea that nation is not a natural but naturalised category.

Having in mind the peculiarly dangerous and self-destructive aspect of the conversion, performed at the outset of the atrocities that the Jewish people were about to experience, the mother's character can be understood from another point of view - one which stems from cultural concepts of the self-inflicted and deeply internalised sacrifice. Even though the future sufferings of Jews and other ethnic communities in the Balkans (especially Roma and Serbs) are foreseeable, the narrator's mother decides to become Jewish. It is her way of identifying with her children and seeking acceptance of her husband's Orthodox Jewish family that never accepted her being Serbian. By contrast, her newly established Jewish identity represents an important element of the socio-cultural role of the martyr, traditionally appointed to the women in the Balkans so they are not only to be interpreted as heroines, but also as victims. She does not attempt to escape the approaching horrors of war, but willingly immerses herself into the role of martyr. ${ }^{16}$

\footnotetext{
${ }^{16} \mathrm{It}$ is important to emphasize that 'the ethics of self-sacrifice is so deep, so vigorously imposed into the consciousness of women in Eastern Europe (and especially in the Balkans) that it cannot simply oppose the logic of individual rights from a liberal tradition'. This means that even though the gesture of self-sacrifice is determined by strong cultural and social ties, women have an important, although limited, space for individual initiative because they do become subjects and individuals through sacrifice, finding a way to suspend their traditionally appointed position of passive objects of patriarchal domination - Marina Blagojević, 'Women and War: the Paradox of Self-Sacrifice or the Anatomy of Passivity', in Gender, Nation, Identity, ed. Dana Johnson, Belgrade: Women in Black, 2005, p. 161.
} 
Here, I said, in Zagreb, she was first a Serb and later a Jew, in any case a foreigner, a double foreigner, if one can put it that way, but she felt, in spite of everything, that she could belong here. ${ }^{17}$

The mother's sense of national affiliation is multilayered because she maintains all these collective identities together and yet, she does not immerse herself into the sense of complete national identification but keeps the sense of estrangement towards any kind of absolute unity and collectivity. In addition to that, one should not forget that it is also the Balkans' specific historical milieu which constantly imposes national identity modifications and changes. By saying 'I never stopped being Serbian' she tries to accept and resolve her inner otherness and at the same time, her constant migrations portray her character as that of the wandering subject, but not a completely nomadic one since she does not fully relinquish a sense of fixed identity. When the war is finished, she takes her children to Jewish school to learn and practice their sense of collectivism and Jewishness, to perform and re-enact identity representations in order to regain their roots - to develop in themselves, and in herself, 'a sense of real belonging, in order to find some solid ground, there where everything was sliding or turning into agitated voice ${ }^{318}$.

Nevertheless, as a female character, she is 'akin to what Foucault called countermemory, a form of resisting assimilation or homologation into dominant ways of representing the self. ${ }^{19}$ Placed at the painfully traumatic identity limits, she is tragically caught in-between the strict national differences, trying not to transcend or subvert them but hold them closely together. That way, the mother succeeds in keeping these differences in the state of inner dialogic tension because none of them should dominate over others.

Meanwhile, in her attempt to save her children's lives, she has to move from Zagreb to the southern regions of the occupied Yugoslavia. Since the South is traditionally and stereotypically represented as the barbaric, pre-civilised remote part of the land, the mother is going from one marginal place to another. Finally, at the end of the war she settles in Peć, in Kosovo, where she does not become close with the Serbian majority, to which she ethnically belongs, but with the Albanians and other marginalised non-Serbs. The mother's voluntary decision to refuse to be a part of the ethnic majority, its politics of

\footnotetext{
${ }^{17}$ David Albahari, Bait, trans. Peter Agnone, Evanston: Northwestern University Press, 2001, p. 34.

${ }^{18}$ Ibid., p. 52.

${ }^{19}$ Rosi Braidotti, 'Difference, Diversity and Nomadic Subjectivity',

$<$ http://digilander.libero.it/ilcircolo/rosilecture.htm>, 1998, [accessed 20 December 2014].
} 
power and oppression, is particularly important at the level of authorial political statement, implicitly present in the novel. Due to her double foreignness and the sense of inner exile, the mother's life in Kosovo is left 'untouched' by the dominant ethnonationalist discourses of the Kosovo myth, which were particularly significant and powerful during the 1990s in Serbia. She relates herself to the Albanians on the grounds of her social and gender aspects of the marginalised and suppressed subject.

The symbolic invisible line which the narrator shows on the map of the former Yugoslavia to his friend Donald is employed to develop an idea that transnational or multinational identities are not just possible: they are the reality of human individual experience, placed within the context of the Balkans at the end of the twentieth century, when national and state borders were constantly being contested and cancelled in a destructive way. This is, also, tragically invoked in the geography of the 'mother's journey which maps the path of World War II and simultaneously anticipates the Yugoslav civil wars in the 1990s that will replay her life in the exile of her son'. ${ }^{20}$

The fact of being a foreigner all the time, a double foreigner, could support the hypothesis that the character of the mother represents a specific type of inner exile, even though it would be difficult to decide, beyond any doubt, whether it is self-imposed or a forced one. Having in mind her decisive nature and her belief that everyone is the blacksmith of his own fate', the mother's internal exile represents the individually performed act of estrangement from the master narratives of the nation, ethnicity and the past. The ambiguity in the mother's character is emphasised through the opposing claims that even though she is a constant double foreigner, she finds a way to create a sense of belonging; her inner exile, within the contexts of the Balkans, resembles the notion of 'exile as the type of home that is always on the move"21.

As the narrator tries to explain the historical turmoil of the Balkans for the last two centuries, the mother's character appears in his story as an illustration of all the difficulties and impossibilities of establishing a historically fixed national identity:

She was born shortly after the fall of a [Austrian-Hungarian] monarchy and the birth of a new country [the Kingdom of Serbs, Croats and Slovenians] and for her

\footnotetext{
${ }^{20}$ Tatjana Aleksić, 'Extrication the Self from History: David Albahari's Bait', Journal of the Midwest Modern Language Association, vol. 39, no. 2, 2006, p. 61.

${ }^{21}$ Maeera Y. Shreiber, 'The End of Exile: Jewish Identity and Its Diasporic Poetics', PML A, vol. 113, no. 2 , 1998, p. 274.
} 
entire life, perhaps, precisely because of that, she wouldn't know to whom she really belonged, which is the most difficult form of belonging. ${ }^{22}$

Having in mind that the mother's country changed its name several times by the end of the twentieth century (The Kingdom of Yugoslavia, National Federative Yugoslavia and finally the Socialist Federal Republic of Yugoslavia which collapsed in the 1990s), the mother's sense of belonging becomes even more ambiguous and even, in a way, ironic. According to Damjana Mraović, 'not only the change of the state name (which in Albahari's linguistic concept has an essential meaning), but also the changes of the political systems did not allow the mother's historical identity to be formed'. ${ }^{23}$

In addition to that, the Balkans' political, cultural and social whirlpool did not allow enough time and stability for the mother's character to recognise herself through the more fixed categories of ethnicity, class and gender. Her life narrative, conveyed within the prevailing atmosphere of historical irony and personal tragedy, offers to the reader the reverse side of the Balkans' image and of its 'distinctly male appeal, the appeal of medieval knighthood, or arms and plots ${ }^{24}$. It is the narrative that shifts the emphasis from the official 'mythistorical nation-forming narratives' to those who define their life histories by counting their losses and defending their own right to remember. ${ }^{25}$

Therefore, the mother's attitude towards history with the capital $\mathrm{H}$ is always related to her refusal of all the modes of truth that are imposing themselves on the individual personality/subjectivity. As Damjana Mraović convincingly explains in her article, the mother's story represents the 'radical critique of historical representation which is always associated with fathers ${ }^{26}$, while the orality of the mother's discourse introduces her as the reliable source of absent and suppressed individual histories. Due to their being connected with the domestic, personal and existentially silenced milieu, women's histories could significantly oppose the grand narratives. They strive to represent underground voices, excluded from the public sphere, and to create an important 'female political space based

\footnotetext{
22 David Albahari, Bait, trans. Peter Agnone, Evanston: Northwestern University Press, 2001, p. 29.

${ }^{23}$ Damjana Mraović, 'The Politics of Representation: Mamac by David Albahari', Serbian Studies, vol. 19, no. 1, 2005 , p. 45.

${ }^{24}$ Maria Todorova, Imagining the Balkans, Oxford: OUP, 1997, p. 14.

${ }^{25}$ Tatjana Aleksić, 'Extrication the Self from History: David Albahari's Bait', Journal of the Midwest Modern Language Association, vol. 39, no. 2, 2006, p. 62.

${ }^{26}$ Damjana Mraović, 'The Politics of Representation: Mamac by David Albahari', Serbian Studies, vol. 19, no. 1, 2005, p. 47. 
on non-male elements (pacifism, non-loyalty, motherhood) confirming that the female representation is possible in the symbolically male space ${ }^{27}$.

The mother's interrupted and mosaic-like narrative stands as the negation of the totality and linearity that are attributed to the commemorative narrative of the historical past. Instead of an ideologically coherent Cartesian set of logical facts and the chronology of the great events from the national mainstream history, the mother's voice offers a decomposed and incoherent testimony, a 'sequence of lucid and mnemonic images ${ }^{28}$. The storytelling, (dis)organised in this way, serves not to dethrone history fully, but to disrupt its ideological and patriarchal grip by inserting the alternative perspective of the silent and unspoken women's histories.

Her actions, traits and destiny exemplify how the personal feminine/motherly view on collective identity could potentially loosen the borders of national identities, constructed according to the ethnic and linguistic purity concepts. Conversely, the mother's profoundly personalised narrative inexorably leads to a strong sense of displacement and estrangement, causing at the end of the novel a great deal of suffering and disillusionment. Therefore, the state of exile, as much as the acts of separation and homelessness, seems inevitable. While the mother's inner exile is determined by her radical denial and refusal of the masculine master narratives of the past, the feminine aspects of the narrator's exile narrative in Canada are inscribed in his writing, its pauses, breaks and fragmented syntax structures.

\section{Donald and the Mother as Exile Mirrors}

Even though the mother is the main narrator of the personal and family life, along with the father as the passive voice of trauma (a camp survivor), it is not completely true that she is the main (although hidden) narrator of the novel as Damjana Mraović affirms $^{29}$. Despite the fact that Bait opens with the sentence 'Where should I begin', thus ambiguously expressing both the narrator's and the mother's sense of anxiety towards historical time, it becomes clear that the narrator is, more or less directly, in charge of the recording process. Even though a very careful listener, he pushes the button and

\footnotetext{
${ }^{27}$ Ibid., p. 48.

${ }^{28}$ Tatjana Aleksić, 'Extrication the Self from History: David Albahari's Bait', Journal of the Midwest Modern Language Association, vol. 39, no. 2, 2006, p. 57.

${ }^{29}$ Damjana Mraović, 'The Politics of Representation: Mamac by David Albahari', Serbian Studies, vol. 19, no. 1, 2005, p. 47. 
afterwards, while living in Canada, he manages the written transposition of the mother's recorded history.

Furthermore, it becomes clear at one point that the narrator, an 'advocate of emptiness $^{30}$, transforms himself into the disembodied narrative voice by closely intersecting his own utterances not just with the voice of his mother but also with the voice of his Canadian friend Donald. Therefore, Donald and the mother could be interpreted not as 'real', individualised figures but the products of the dialogue that takes place within the narrator's consciousness. ${ }^{31}$ In this 'exchange of voices where the narrator gives voice to family members or inhabitants of their new homeland ${ }^{32}$, it is still the narrator's voice that holds the principal authority in the novel, thus creating a sense of monological narration.

In terms of Bakhtinian dialogism and heteroglossia, the characters of Donald and the mother are not given the sufficient level of ideological and linguistic independency; their utterances are mostly reflected through the narrator's conscience, and therefore they are employed mostly as the narrative and identity mirrors for the narrator's own exile dilemmas. The dynamic of this mirroring process is determined by two important facts: the narrator cannot accept his mother's ambiguous inscriptions of gender and ethnic multiplicity and also, it is impossible for him to accept the modes of existence, embodied in the narrator's acquaintance Donald who represents a 'typical Canadian or Northern American' in opposition to the narrator's European, Yugoslav and Balkan background.

While Donald expresses his ideas about strong, plausible and socially motivated narratives and plot structures, inviting the narrator to accept the real world and not the world of paper (the world of fictional literature), the narrator pleads for the notion of the self as the multilayered and dissonant entity. This issue is presented through the laconic comparison of different practices in coffee drinking: according to Donald, one of the crucial differences between highly developed nations and those that are underdeveloped lies in the fact that 'backward' nations drink their coffee with the coffee grounds in it. Since Donald himself is a descendent of Ukrainian immigrants, his cultural and individual identity exemplifies one of the possible solutions of the exile drama. Born in Canada, he

\footnotetext{
30 Tatjana Aleksić, 'Extrication the Self from History: David Albahari's Bait', Journal of the Midwest Modern Language Association, vol. 39, no. 2, 2006, p. 54.

${ }^{31}$ Robert Hodel, Diskurs (srpske) moderne, Beograd: Filološki fakultet: Institut za književnost i umetnost: Čigoja štampa, 2009, p. 183.

32 Vladimir Gvozden, 'Images of Canada in the Contemporary Serbian Novel: David Albahari's The Man of Snow and Vladimir Tasić's Farewell Gift, in Other Language - Otherness in Canadian Culture: proceedings / First International Conference on Canadian Studies, Belgrade, 18-20 October 2003, ed. Vladislava Felbabov and Jelena Novaković, Niš: Tibet, 2005, p. 125.
} 
has internalised all the cultural modes and models of the Canadian milieu, while thoroughly erasing any connection to the Ukrainian 'roots' because these roots represent the unwanted coffee sediment and the unsettling sense of difference and estrangement.

In contrast to Donald, the narrator cannot suppress or resolve the immense variety of cultural and identitary sediments which are created not just by his Balkan past, but by the general history of Europe. In the conversations with Donald, the narrator evokes the whole range of cultural, social and political stereotypes, and organises them in accordance with the binary opposition model (Europe/America, South/North, Canada/Europe, collectivism/individualism, activity/passivity). These stereotypes help him to look for the proper performative act or cultural gesture that would resolve his own psychological and mental struggles, because the narrator constantly pendulates between the need to inscribe permanently the borders of collective identities and the necessity of embracing the radical rupture. He feels that he has to extricate himself completely from the deadly embrace of the History that made his mother's life and his own exile experience almost unbearable.

In light of this, Donald represents one of the possibilities: his character embodies the type of individual who is capable of denying the deadly call of History. However, when confronted with Donald in their numerous discussions in the cafe, the narrator is unable to let go his own cultural background and the complexity of European identities, which reveal not only the narrator's fears of the newly acquired language and culture, but also his own sense of self-pity that is particularly typical of intellectuals in exile. ${ }^{33}$

On the other hand, his relationship with the mother reveals that he is also trying to cut the psychological, national and cultural ties that hold him connected to his language and his country (or countries, having in mind the collapse of former Yugoslavia in the 1990s). Consequently, the narrator's unspoken objectives in regards to the tape recording are both more complex and ambiguous: at the same time, he is the one who voices his mother's story but also, and up to a certain level, he silences the mother's alterity and subjectivity in order to self-define his exile status and construct the mode of identity that would be equally distanced from the dominant discourses of the Canadian, European and Yugoslav (trans) national identities. 'As much as his narrative reads as an hommage to his mother, it is much more an attempt of self-liberation, which necessitates that the memory of her and all she symbolises be laid to rest' (Aleksić 2006: 55).

\footnotetext{
33 According to Joseph Brodsky, the exiled writers constantly look towards the safe territory of their past, no matter how difficult or traumatic it was, because that mechanism is both the means of remembering the past and the tool necessary for the postponement of the coming present that frightens the exiles the most. See: Joseph, Brodsky, On Grief and Reason: Essays, New York: Farrar, Straus and Giroux, 1997.
} 
Similar to the infant's fort/da game, described in the Freud's story about his grandson's playing, the narrator's view of his mother's voice reveals that he is primarily interested in resolving his own identity issues; being cut off physically from his homeland and having the tapes with the voice of the dead mother, the narrator tries to reenact an infantile psychological drama of separation between the child and its mother. ${ }^{34}$

By pushing the button on and off, he assumes the position of someone who tends to determine the dynamics of the mother's presence and absence so his 'original idea to textualize Mother's speech represents the ultimate death blow to her story that he is trying to pull off for the sake of his own redemption'. ${ }^{35}$ In light of this, the potentially subversive force of the mother's multifaceted identity, together with the non-patriarchal quality of her silenced oral history, remains insufficiently elaborated in the novel. It seems that her continuous historical experience of inner exile represents a burden of anxiety too difficult for the narrator to endure, even though the mother's proactive, willing and alternative oral discourse could be employed as the means of finding the 'crack' within the monolithic patriarchal discourse of the nation.

The way the narrator relates to his mother's voice resembles the way different psychoanalytic theories depict the relationship between the mother and the infant in the pre-Oedipal stage of development. As Jane Gallop affirms, in both Lacanian theoretical models of the mirroring process and the object-relations psychoanalytic theory a mother's role is always to 'complement the infant's subjectivity; in neither story is she ever a subject $^{36}$. Therefore, it could be said that by openly and sometimes obsessively embracing the motherly figure in the novel, the narrator constantly obliterates her otherness, which is implicitly introduced at the beginning of the novel where the image of the audio tapes is given:

The jacket, folded, had been placed at the top of the suitcase and wouldn't have been able to protect them from a more forceful blow; after all, the cardboard boxes in which they'd been packed would have protected them more, but the sleeves of

\footnotetext{
34 Sigmund Freud, 'Beyond the Pleasure Principle', in The Standard Edition of the Complete Psychological Works of Sigmund Freud, vol. XVIII, London: The Hogarth Press, 1958, pp. 1-64; Zoran Milutinović, 'The Demoniacism of History and Promise of Aesthetic Redemption in David Albahari's Bait', Serbian Studies, vol. 19, no. 1, 2005, pp. 15-24.

35 Tatjana Aleksić, 'Extrication the Self from History: David Albahari's Bait', Journal of the Midwest Modern Language Association, vol. 39, no. 2, 2006, p. 63.

${ }^{36}$ Jane Gallop, 'Reading the Mother Tongue: Psychoanalytic Feminist Criticism', Critical Inquiry, vol. 13, no. 2, 1987 , p. 324. 
the jacket, which I had folded across them, after having secured them with elastic bands, had eased the insecurity I felt. ${ }^{37}$

Nevertheless, his narrative shows strong resemblance to the mother's voice structure which is particularly evident in the narrator's attempt to replace the 'oral properties of his mother's story with the written ones of his text ${ }^{38}$. He floats symbolically within the empty space between the oral phase of his homeland culture and the Canadian culture embodied in Donald's idea that the fictional stories have to include strong plots, clear composition and vivid characterization. As he cannot endure his mother's model of the inner exile and her life choices, because it would mean living in the unbearable midst of the war conflicts of the 1990s, he tries to recreate a new sense of identity in external exile. In this transition, some traces of the mother's feminine subjectivity appear homologous to the narrator's writing that, although primarily involved in the postmodern meta-narrative and narrative suspension, also invokes the core hypotheses encompassed in the notion of the l'ecriture feminine, elaborated by French feminists Julia Kristeva, Lucy Irigaray and Helene Cixous. ${ }^{39}$

Even though the model of l'ecriture feminine can justifiably be criticised as essentialist, idealist and theoretically fuzzy, the suggestions relating to language distortion and subversion made by Julia Kristeva could still be useful for literary analysis. 'The gestural, rhythmic and prereferential language' that Kristeva recognises in the writings of Joyce, Mallarme and Artaud is similar to Albahari's deconstructed narrative and loose plot structure, distorted time frames, self-reflective discourse, fragmented sentences, pauses and silences. ${ }^{40}$ On the one hand these elements make the narrator's utterance appear to be, to a certain point, an almost antipaternal discourse, but on the other, Kristeva's view of the mother/infant relationship also shows that the mother is silenced as the one who provides blissful fusion for the child while her otherness rests unspoken and unarticulated.

Together with other structural elements, the language in Albahari's novel is also simultaneously the means of obstructing the plot development, transforming it constantly into a series of smaller episodic scenes, essay-like comments and digressions, and the

\footnotetext{
${ }^{37}$ David Albahari, Bait, trans. Peter Agnone, Evanston: Northwestern University Press, 2001, pp. 3-4.

38 Tatjana Aleksić, 'Extrication the Self from History: David Albahari's Bait, Journal of the

Midwest Modern Language Association, vol. 39, no. 2, 2006, p. 62.

${ }^{39}$ Julia Kristeva, Revolution in Poetic Language, New York: Columbia University Press, 1984; Julia Kristeva, Strangers to Ourselves, New York: Columbia University Press, 1994; Lucy Irigaray, Speculum of the Other Women, Ithaca: Cornell University Press, 1985; Lucy Irigaray, The Sex Which is Not One, Ithaca: Cornell University Press, 1985; Susan Sellers, ed., The Helene Cixous Reader, London: Routledge, 1994..

40 Ann Rosalind Jones, 'Writing the Body: An Understanding of 'L'Ecriture Feminine”, Source Studies, vol. 7, no. 2, 1981, p. 248.
} 
arena for examining the relationship between the national identity and feminine figures. Although it may seem that the narrator's interest in the complexities of the language and identity propels him to introduce a wide range of verbal and non-verbal differences, stemming from his mother's feminine and corporeal experience, nevertheless he holds the dominant monological position in the novel. Instead of voicing the otherness of his mother's subjectivity that would perhaps establish a new mode of living on the borders of various identities, the narrator uses her character as a psychological and existential mirror in order to regain his own sense of self, trying to resolve the trauma of his external exile.

Confronting himself with Donald and the mother, he heads for the exile position that resembles the notion of the exile's space, elaborated in the writings of Julia Kristeva. The narrator of Bait represents himself as the intellectual who 'constantly put structures and meanings in question' and the eccentric foreigner whose strangeness becomes a threat to the social fabric represented in the character of Donald.

The exile's sense of space is so dislocated that he can no longer affirm the security of a psychic interior or the comforts of a normatising, transcendent exterior (the father, the Law, God). There is no place that offers itself as home. ${ }^{41}$

Therefore, he positions himself outside of culture. By claiming the exile outside of culture and language, the narrator reveals that he is not capable of fully accepting and voicing the mother's gender subjectivity and the inner exile difference that could 'shackle the ideological weight' in the patriarchal concept of the national identity and articulate a fundamental sense of diaspora. It is the mother's sense of inner exile that could be seen as the type of a home that is always on the move', despite all the difficulties and tragic events in her life.

\section{The Unspoken Language of (M)other?}

Considering the mother's subversive subjectivity, it is worth discussing the significance of the wide range of language issues inscribed in the mother's character in the novel: the mother's literary skills, the richness of her oral discourse, her Scherezade-like storytelling, the symbolic implications of the phrase 'mother tongue', and the importance

\footnotetext{
${ }^{41}$ Anna Smith, Julia Kristeva. Readings of Exile and Estrangement, New York: St Martin's Press, 1996, p. 24. 
and the influence of non-verbal elements of the narrator's native language (sounds, melodies, silences, tones and moods). By closely reading these aspects, one could reach the subtle and multidimensional answer to the following question: How and to what extent does Albahari's narrator succeed in creating an alternative language with the sufficient subversive strength to 'shackle the ideological weight" ${ }^{42}$ in the patriarchal concept of the national identity, or provide new modes of the exile experience?

The fact that the mother's oral discourse provides authority for the narrated fragments of history could additionally be understood within the context of the traditional role that oral forms of literary expression played in the Balkan nations' past. Unlike the epic poems that glorify mythic or historical male figures, the forefathers of the collectivity - thus, constituting the holistic 'body of the Norean 'traditional memory', which is deposited into the collective consciousness' - the presence of lyrical genres in the mother's speech emphasises those subaltern historical narratives. ${ }^{43}$ Fairy tales and lyrical songs called sevdalinke $e^{44}$, performed by the mother when the children were younger, represent genres traditionally sung by women. In these songs, melody, rhythm and sound were features of great significance since they communicated the textual meaning at the intuitive and emotional level of the listeners:

Mother knew how to use rhythms, to intertwine several folk narrative phrases, to line up a row of adjectives, to scramble the structure of a sentence, to tell a story. We sat around her captivated, intoxicated with suspense, shrouded by the tangled grapevine, until the darkness would completely blot out our faces. I have never seen darkness so thick as in Bosnia. ${ }^{45}$

The way the mother uses traditional narrative forms and phrases reveals subtle inscriptions of her femininity: her playing on words and the inverted word order resemble the process of weaving/embroidering, historically perceived as crafts mainly done by women. But, as can be seen from the quotation, the narrative structure of the epic story is not completely deconstructed (the mother can still intertwine several folk narrative

\footnotetext{
42 Jane Gallop, 'Reading the Mother Tongue: Psychoanalytic Feminist Criticism', Critical Inquiry, vol. 13, no. 2, 1987, p. 319.

${ }^{43}$ Tatjana Aleksić, 'Extrication the Self from History: David Albahari’s Bait', Journal of the Midwest Modern Language Association, vol. 39, no. 2, 2006, p. 58.

${ }^{44}$ A specific type of melancholy-driven poem, usually love poems that express the overall feeling of sevdah: the feeling when you are incapable of enduring the pain caused by love, and the pain transforms into the ecstasy of the intoxication of love that compares to the slow process of dying.

${ }^{45}$ David Albahari, Bait, trans. Peter Agnone, Evanston: Northwestern University Press, 2001, pp. 31-32. 
phrases and tell a story). Therefore, this ambiguity establishes a very significant analogy: similar to the mutually intertwined epic and lyric genres in the mother's discourse, masculine master narratives of national identity become destabilised from within, by the voice of the oral, feminine and personal history. Since the mother embodies the concept of ambiguity, her character is used at the same time to construct and deconstruct the patriarchal image of the nation. Her marginal position, the unresolved state of belonging and the way she constantly oscillates between the centre and the margin, are depicted through the image of her geographical descent towards the South during the Second World War.

Furthermore, it is important to stress the contrast between the mother's telling of tales and singing of songs (which happens in the private setting of the family home) and the literary elites of Serbia who, at the end of the twentieth century, spun 'tales of betrayal and tragedy, unique gifts and messianic roles' in order to articulate a new sense of national collectivity since the model of Yugoslav brotherhood and unity was rapidly collapsing. ${ }^{46}$ While the mother's story resembles the narrative weaving of Scheherazade that resists death and destruction, the national elites of the 1990s provided epic-like stories that were used by the ethnocratic groups and individuals who 'embellished these stories with 'facts', constantly moving or sliding between the everyday world of politics and the otherworldly sphere of heroes, sacred spaces, martyrs and traitors - naturalizing the patriarchal values expressed in their romantic vision of the nation'. ${ }^{47}$

At the end of the description of the mother's storytelling, an almost apocalyptic detail of the dark in Bosnia foreshadows tragic events in the 1990s (the conflicts in Croatia and Bosnia); their metaphysical repetitive nature cannot be escaped even by the mother's magical embroidering narrative. In addition, the detail of the tangled grapevine, met with the prevailing darkness, form a symbolic border that limits the extent and the potentially subversive power of the mother's discourse. Even though her skilful nature always finds a way to reverse and playfully upend the laws and the horizons of expectations, characteristic for the poetry genres, it is only to the extent of creating a very personal familial atmosphere, suppressed by the tragically aggressive narratives of war and bloodshed.

\footnotetext{
${ }^{46}$ Julie Mostov, 'Sexing the Nation / desexing the Body: politics of national identity in the former Yugoslavia', in Gender Ironies of Nationalism: Sexing the Nation, ed. Tamar Mayer London: Routledge, 2000, p. 92. 
If the mother's masterful literary skills fail to disturb the patriarchal order of history seriously, Albahari's narrator offers an alternative code that could, perhaps more successfully, articulate the mother's subjectivity and her peculiar personal exile. Reluctant to speak at the beginning of the novel, the mother, afterwards and aside from her verbal expression, accumulates a wide set of different non-verbal sounds, also recorded as an important addition to her voice: silences, pauses, the muffled noises of her crying and sniffing, her footsteps on the kitchen floor and the scraping of the chair where she sits embarrassed because of the tape recording. These seemingly unrelated signs of the mother's physical presence constitute her own language of gestures and of the body, which partially attempts to dislocate and cancel the possibility that the History might resurrect itself if mother provides it with words. Also, as Tatjana Aleksić points out, the mother's corporeal language represents an example of Sigrid Weigel's concept of the corporeal memory where it is not possible for the gesture to be translated into language, since 'its significance is disclosed only through the recollection of the form and experience actualised within it $^{48}$. Unlike the mother's gestural language, the narrator's discourse tends to efface his own traces of corporeal existence. Not that he ever mentions his bodily functions or sensations, but his discourse places a strong emphasis on the verbal aspects of communication so the world with its physicality and materiality becomes dissolved into the words. And since the narrator's utterance is diffused with his mother's and Donald's speech, the narrator becomes a disembodied voice which favours the mind, thus leaving the body silenced, and again suppressing the possibility of hearing the mother's otherness within his own experience of the external exile.

As far as the general issue of language is concerned, the mother is in several cases undoubtedly identified with the native language which the narrator is trying to forget or suppress in order to establish the new life environment in Canada. Also, it is significant that the language we speak is usually called mother tongue or mother language. In the case of Albahari's novel, it is not only the language that the character learns from his mother, but it is also the one that communicates traces of certain pre-oedipal images of the relationship between the mother figure and her infant:

And that's why, when I heard Mother's voice, I winced, not because her voice had come, as commonly said, from the other side of the grave, but because I felt, and

\footnotetext{
48 Sigrid Weigel quoted in Tatjana Aleksić, 'Extrication the Self from History: David Albahari’s Bait, Journal of the Midwest Modern Language Association, vol. 39, no. 2, 2006, p. 58.
} 
that like real pain, how my language was dragging me away from my new host and returning me with great speed to my original form. ${ }^{49}$

The effect of the language in the mother's speech is physically transparent and the image of the narrator's sense of return to his primal form reveals a specific, romantic notion of the language as the tool that bonds our subjectivity to our collective, precivilised and pre-modern grounds. Since it is his mother's voice, this return could be interpreted in psychoanalytical terms as the narrator's fears of the return to the uterine state of life and mind. The ambiguous quality of the narrator's attitude towards his mother's character stems from the fact that she embodies not just the parental figure but the whole very complexly interwoven imagery of the nation, homeland and the native language. The drama of the narrator's exile is the drama of his psychological separation from the mother. Therefore, he tries to gain a new sense of identity, by escaping the detrimental restorative power of the mother tongue since language is one of the most powerful tools and mediums of history, memory, the past and all inherited identities that the narrator was born into:

The whole time I was tormented by the fear that a return to my native language, reinforced by the fact that it was precisely my mother who was speaking it, would bring me back to where I no longer wanted to return, especially now that, thanks to someone else's language, I was finally beginning to feel like someone else..$^{50}$

While resolving his new state of exile, the narrator describes his encounters with his fellow men. He never approaches them nor does he try to understand the content of their speech:

I go from store to store, uninterested in what they are really saying, because it is mostly shouts of warning directed at the children or malicious comments about the quality of the merchandise here, but I am eager to drown in that sea of sounds; only in it am I able to feel natural. Not one of their words managed to reach me, but that's why each of their voices was also mine, and I formed my lips mutely, moved

\footnotetext{
${ }^{49}$ David Albahari, Bait, trans. Peter Agnone, Evanston: Northwestern University Press, 2001, p. 28.

${ }^{50}$ Ibid., p. 106. 
my tongue, prepared a hum of the vocal cords, adjusted the resonance of the oral cavity. ${ }^{51}$

It is the sound and the melody of the mother language that is the only valuable thing, because at that level, the relationship between the narrator and his past or his origins could not be contaminated by the discourses of war, nationality or ethnicity. The sea of sounds represents an almost mythical place of unity that transcends historical circumstances. At the same time the source of life and the element of destruction, in the psychological symbolic sense the water stands for those elementary unconscious forces of the human psyche. But it also represents a connection with the chthonic world beyond. Therefore, the mother's voice, coming from the tapes, simultaneously implies the seductive force of the dead and the possible source of new strength, needed for the exile life in Canada. In addition to that, it is important to notice at the end of the quotation how Albahari does not allow for the tragic or melodramatic atmosphere to prevail, finding a counterbalance in the image of the mute comic pantomime of a man humming.

Building a fragmented, sometimes self-involved fictional autobiography, the narrator of Bait constantly incorporates a variety of gender or femininity/masculinity issues, indirectly suggesting that the engendering of national identity and the exile experience could help articulate alternative types of discourses, non-patriarchal and non-ideological, those that would strongly and effectively oppose the grand narratives of History. In that light, the narrator's mother appears to stand for that different model of national identity, fragmented and paradoxical from within. Being Serbian, Jewish and Yugoslav at the same time, she does not superficially express but fundamentally and actively lives her multiplied sense of belonging, accepting her own inner modes of otherness. Her verbal and non verbal skills, refusal to surrender to the mythistorical narrative of the nation's past, and the richness of her gestural language reveal the presence of the subjectivity that is neither masculine nor motherly. It is the subjectivity which perpetually stands in the middle, between and along the borders of various national, class and gender identities. But, even

\footnotetext{
${ }^{51}$ Ibid., pp. $76-77$. 
though it might seem that this particular model of the mother's otherness could overcome the patriarchal imagery of the nationalism and its rigid structures, it is strongly confined within the life of an internal exile that stays tragically muted. On the one hand this could be explained as the consequence of the whole range of socio-historical conditions in the Balkans during the 1990s, but on the other, the failure to articulate fully the otherness of the mother's subjectivity is caused by the setting of the event of narration (as opposed to the narrated events in the mother's story).

If one is to consider the conditions of the narrative production, then the narrator's trauma of external exile is one of the main reasons why the mother's subjectivity and the whole range of performative effects, initiated by women's unspoken experiences, stay unexplored and undeveloped. Fleeing from the Yugoslav conflict and trying to find his own sense of identity, the narrator uses his mother's voice and its complexities not to open himself to the alterity of the paternal and patriarchal discourses but to mirror his own anxieties, uncertainties and identity dilemmas. Although there are elements of the l'ecriture feminine in the narrator's writing, which demonstrate how difficult it is to 'cut the maternal source of words ${ }^{52}$, his main objective is to separate himself from his mother's figure and the national identities she embodies. In order to live another type of exile, different from that of the mother's, he attempts to provoke the rupture with the past and distance himself from the historical experience of his homeland by embracing another language and listening to his Canadian friend Donald. Nonetheless, he remains 'charmed' by the primal sounds of his mother tongue, although avoiding direct contact with his compatriots in Canada. And, even though by the end of the novel everything remains unresolved - the narrator's own subjectivity still floating between his mother's voice and the voice of Donald - the issue of gender ambiguity proves to be one of the most important features in the novel; it does not 'shackle the ideological weight of the patriarchal discourse, ${ }^{53}$ but hopefully it reveals the amounts of possible ruptures in the masculine order of the text.

This work is licensed under the Creative Commons Attribution-NonCommercial-ShareAlike 4.0 International License. This lets others remix, tweak, and build upon the author's work non-commercially, as long as they credit the author and license their new creations under the identical terms. To view a copy of this license, visit http:// creativecommons.org/licenses/by-nc-sa/4.0/.

\footnotetext{
${ }^{52}$ Julia Kristeva quoted in Tatjana Aleksić, 'Extrication the Self from History: David Albahari's Bait', Journal of the Midwest Modern Language Association, vol. 39, no. 2, 2006, p. 61.

53 Jane Gallop, 'Reading the Mother Tongue: Psychoanalytic Feminist Criticism', Critical Inquiry, vol. 13, no. 2, 1987, p. 319. 